\title{
POLA KOMUNIKASI DAKWAH KOMUNITAS MUSLIM DALAM MENJAGA HARMONI SOSIAL
}

\author{
Yohandi \\ Program Studi Komunikasi dan Penyiaran Islam \\ Institut Agama Islam Negeri Jember
}

\author{
Khusna Amal \\ Institut Agama Islam Negeri Jember
}

Diunggah 02 Oktober / Direvisi 15 Oktober / Diterima 16 November 2019

\begin{abstract}
Abstrac: Da'wah is not only understood by the meaning but also as a science, but must be understood as a noble behavior to create a happy life both in the world and hereafter. Thus, da'wah has moral responsibility to fulfill the intended purpose. Because da'wah is the process of conveying religious messages, da'wah cannot be separated from the communication process. In other words, preaching must pay attention to the principles of communication, especially in terms of patterns of intercultural communication, especially when the mission is delivered in the midst of nonMuslim communities. This paper has three main issues, are: 1) the concept of understanding the importance of maintaining harmony; 2) the da'wah strategy in the midst of the Hindu community, so that it does not adversely affect social harmony; and 3) the pattern of relations between Muslim and Hindu communities in maintaining social harmony. These three issues are the focus of writing this article. This paper gives the message that survival while maintaining harmony in differences is an obligation. Religious differences should not be a barrier to staying together, socializing and side by side. Because in essence every religion craves peace and harmony in the life of the nation and state.
\end{abstract}

Keywords; Da'wah communication, Muslim community, social harmony

Korespondensi: Yohandi \& Khusna Amal

Pascasarjana IAIN Jember 


\section{A. PENDAHULUAN}

Indonesia sebagai negara yang menganut asas tunggal Pancasila dan Bhinneka Tunggal Ika, Indonesia menjamin kebebasan beragama dengan tetap memperhatikan persaudaraan, perdamaian dan kesejahteraan para pemeluknya. Hal ini sesuai dengan ketentuan yang ada pada pasal 29 ayat 1 dan 2 UUD 1945 tentang kebebasan beragama. Isi pasal tersebut adalah 1) Negara berdasarkan atas Ketuhanan yang Maha Esa dan 2) Negara menjamin kemerdekaan tiap-tiap penduduk untuk memeluk agamanya masing-masing dan beribadat menurut agamanya dan kepercayaannya itu.

Meskipun berbeda agama, namun pemahaman atas posisi masing-masing penganut menjadi kata kunci penting bagi keselarasan dan keharmonisan kehidupan umat beragama serta menghindari terjadinya perpecahan antara umat beragama. Salah satu bentuk perwujudannya adalah dengan menunjukkan sikap toleransi dalam kehidupan beragama. Selain itu, sikap bertoleransi harus menjadi suatu kesadaran pribadi yang selalu dibiasakan dalam wujud interaksi sosial. Toleransi dalam kehidupan beragama menjadi sangat mutlak adanya dengan eksisnya berbagai agama samawi ${ }^{1}$ maupun agama $\operatorname{ardli}^{2}$ dalam kehidupan manusia.

Masyarakat yang mengalami pemilihan sosial secara terkonsolidasi, cenderung mengembangkan identitas yang kuat dan lebih mudah menciptakan kohesi kelompok yang kokoh. Hal semacam inilah yang dapat menimbulkan konflik yang cenderung tinggi. Sebagai akibatnya, ketika sebuah kelompok terlibat konflik dengan kelompok yang lain, maka intensitas konflik tersebut cenderung tinggi. Individu-individu dalam masyarakat dengan konfigurasi pemilihan sosial yang terkonsolidasi cenderung lebih mudah melakukan subyektivitas konflik.

Mereka juga lebih mudah untuk menerjemahkan konflik yang menyangkut kondisi obyektif (objective conflict) menjadi konflik yang menyangkut pribadi (subjective conflict), misalnya konflik mengenai persoalan antaragama yang berbeda (inter-religious). ${ }^{3}$ Karena itu jika terjadi konflik bernuansa agama diantara penganut agama yang berbeda mestilah dilihat tidak hanya dari sudut agama saja, melainkan

\footnotetext{
1 Agama samawi atau disebut juga agama langit, adalah agama yang dipercaya oleh para pengikutnya dibangun berdasarkan wahyu Allah

2 Agama Ardli adalah agama yang berkembang berdasarkan budaya, daerah, pemikiran seseorang yang kemudian diterima secara global

${ }^{3}$ Nasaruddin Umar, "Interfaith Dialogue dalam Mengembangkan Kehidupan Beragama yang Harmoni dan Damai”, Jurnal Bimas Islam, vol. 6, No.4 (Jakarta: Institut PTIQ, 2013), 628.
} 
juga dari sudut budaya, ekonomi, dan politik, serta akibat dari ketidak efektifan komunikasi yang dibangun oleh orang-orang yang berbeda agama.

Misalnya secara kasuistik, ada beberapa fenomena gesekan antar kelompok agama dalam suatu daerah yang kelompoknya terdiri dari kelompok mayoritas nonmuslim dan minoritas muslim. Misalnya tragedi pembakaran gereja dan bentrok antar warga yang terjadi pada Selasa, 13 Oktober 2015 di Kampung Sukamakmu, Kecamatan Gunung Meriah, Kabupaten Aceh Singkil dan kejadian yang sama juga terjadi pada 17 Juli 2015 yaitu pembakaran masjid di Kabupaten Tolikara oleh umat Nasrani menjelang shalat Id. Karena memang faktanya, pemeluk suatu agama akan lebih bangga dengan agamanya sendiri, namun jangan sampai kebanggan ini menciptakan racun yang menimbulkan permusuhan dan perpecahan diantara umat beragama seperti pembakaran rumah ibadah yang terjadi di Aceh dan lainnya. ${ }^{4}$

Adanya hubungan antarumat beragama itu dimulai dari bagaimana mereka membangun komunikasi antar budaya dan agama masing-masing. Komunikasi antarbudaya terjadi bila pengirim pesan adalah anggota dari suatu budaya lain. ${ }^{5}$ Sama halnya dengan komunikasi antar agama yaitu proses komunikasi terjadi dengan orang-orang yang berbeda agama.

Islam sendiri mengajarkan toleransi yang sangat dalam kepada pemeluknya, bagaimana melakukan interaksi dengan non muslim, membangaun komunikasi dan memperlakukan non muslim dengan sangat bijaksana sampai kepada memberikan kebebasan untuk melaksanakan dan mengamalkan kepercayaan dan keyakinannya sendiri. Hal ini bisa dilihat secara jelas pada Al-Qur'an surah Al-Kafirun ayat 1-6 :

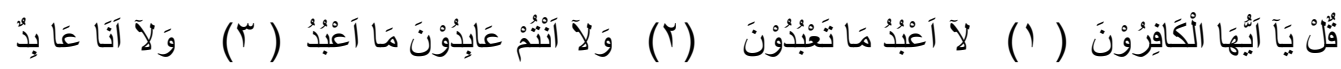

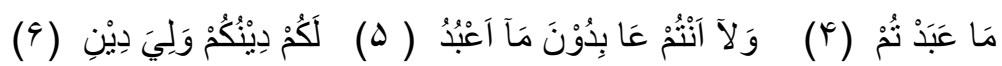

Artinya : Katakanlah: "Hai orang-orang kafir. aku tidak akan menyembah apa yang kamu sembah. dan kamu bukan penyembah Tuhan yang aku sembah. dan aku tidak pernah menjadi penyembah apa yang kamu sembah,dan kamu tidak pernah (pula) menjadi penyembah Tuhan yang aku sembah.untukmu agamamu, dan untukkulah, agamaku."

Bentuk-bentuk komunikasi antar budaya meliputi bentuk-bentuk komunikasi lain, yaitu komunikasi antara kelompok agama yang berbeda. Seperti

\footnotetext{
${ }^{4}$ Ma'had Aly PP. Salafiyah Syafi'iyah Sukorejo Situbondo, "Tanwirul Afkar”, (November , 2015), 10.

5 Deddy Mulyana dan Jalaluddin Rahmat, Komunikasi Antar Budaya (Bandung: PT Rosdakarya,2010), 12.
} 
umat beragama Muslim dan Hindu yang ada di Desa Loloan Barat Kecamatan Negara Kabupaten Jembrana Bali. Loloan merupakan salah satu Kampung yang ada di Kabupaten Jembrana yang terkenal dengan nilai keharmonisan antar umat beragama, khususnya di kalangan umat Muslim dan Hindu.

Islam sebagai agama dakwah tentu memiliki kewajiban untuk menyampaikan ajaran-ajarannya kepada umat manusia khususnya umat Islam termasuk masyarakat non Muslin dalam hal ini adalah komunitas Hindu di Desa Loloan Barat.

Bali dikenal luas sebagai pulau Dewata, negeri para Dewa. Identitas itu dilekatkan pada pulau Bali, bukan hanya karena mayoritas penduduknya memeluk Hindu, namun karena agama Hindu sedemikian melembaga dalam kebudayaan masyarakat Bali. Semua aspek kebudayaan Bali pada hakikatnya dilandasi oleh nilai-nilai yang bersumber pada ajaran agama Hindu. Hindu mewujud dalam berbagai dimensi kehidupan, mulai dari pandangan hidup masyarakat Bali, senibudaya, adat-istiadat, hukum adat, tata ruang, tata bangunan, organisasi sosial kemasyarakatan stradisional, sampai sistem pengaturan hidup bersama dalam komunitas.

Berdirinya kampung-kampung Islam dan tersebar dibeberapa daerah seperti Pegayaman (Buleleng), Palasari, Loloan dan Yeh Sumbul (Jembrana), Nyulin (Karangasem), hingga kampung Islam di Kapoan (denpasar), tidak terlepas dari perlindungan penguasa-penguasa lokal atau Puri di Bali. Para pengasa Puri memberikan tanah, yang disebut tanah catu, pada kelompok migran muslim. Di tanah catu tersebut kemudian dibangun pemukiman yang akhirnya berkembang menjadi wilayah kampung. Selain itu, secara tradisi, wilayah kampung diberi semacam otonomi oleh penguasa lokal untuk menyelenggarakan sendiri urusan keagamaan dan pemerintahannya, seperti memilih pemimpin mereka sendiri, memiliki kelembagaan kampung sesuai dengan tradisi mereka, atau mendirikan tempat ibadat. Pada saat yang sama mereka menjadi loyal sehingga dapat dimobilisasi untuk kepentingan Puri. Ikatan patronase ini menjadi basis hubungan antara komunitas muslim dengan penguasa tradisional.

Proses inkulturasi dengan budaya Bali terlihat juga dari tradisi warga kampung dalam memberikan nama depan anaknya, dengan nama khas Bali, semisal Wayan, Nyoman, Nengah, Ketut. Sementara nama belakang menggunakan nama 
khas Islam, seperti Muhammad, Ahmad, dan sebagainya. Selain bermukim di kampung, warga migran Muslim juga berdiam dan berbaur dengan warga Bali yang beragama Hindu. Dalam model seperti ini, walaupun tinggal di desa adat, warga muslim yang tidak terlibat dalam kegiatan institusi desa adat, tetap memperoleh perlindungan dan pelayanan dari desa dinas.

Gambaran tersebut di atas berlaku di semua kampung-kampung Islam yang ada di Provinsi Bali, tidak terkecuali Desa Loloan Barat yang menjadi tempat penelitian ini. Umat Muslim dan Hindu yang ada di Desa Loloan Barat ini sejak dulu sampai sekarang selalu terlihat rukun, damai, dan harmonis. Belum pernah dijumpai adanya konflik yang sampai menimbulkan perpecahan secara sosial, mereka selalu berdampingan antara masyarakat Muslim yang kebetulan menjadi masyarakat mayoritas dan masyarakat Hindu yang menjadi masyarakat minoritas di Desa Loloan Barat ini. Mereka mampu memperlihatkan sikap harmoni sosial lewat beberapa kegiatan-kegiatan yang di dalamnya mengandung nilai-nilai keharmonisan antar umat yang berbeda agama.

Disamping itu, masyarakat Loloan dalam hal menghadapi konflik tidak menjadi suatu permasalahan yang sangat besar, sebab konflik yang terjadi tidak sampai melibatkan ketidaknyamanan masyarakat Loloan. Dalam pergaulan seharihari, masyarakat Desa Loloan Barat tetap menjaga komunikasi mereka dengan prinsip saling menghargai dan menghormati setiap hal yang berhubungan dengan agama dan budaya semata-mata untuk menjaga keharmonisan sesama umat beragama.

Saat ini keberadaan Muslim di Desa Loloan Barat ini tentu sangat berbeda dengan keberadaan Muslim di daerah lain di Provinsi Bali yang menjadi minoritas dibandingkan dengan masyarakat Hindu. Namun hal ini tidak menjadikan Muslim di Loloan menjadi Muslim yang tidak perduli terhadap komunitas lain. Mereka sadar betul betapa Islam sangat menjunjung tinggi arti sebuah persatuan dan toleransi yang saling menghormati dan menghargai setiap perbedaan.

Faktanya saat ini adalah pekembangan komunitas muslim yang ada di Desa Loloan Barat begitu sangat signifikan, pelaksanaan dan proses dakwah terus dilakukan sesuai dengan tuntunan, mekanisme dan aturan-aturan yang berlaku tanpa ada perlawanan dan gangguan dari pihak manapun, termasuk dari kelompok yang mayoritas di Bali yaitu komunitas Hindu. Namun yang paling penting adalah 
kemampuan komunitas muslim dalam melaksanakan kewajiban untuk berdakwah dengan tetap menjaga keharmonisan ditengah-tengah masyarakt.

\section{B. PEMBAHASAN}

\section{Komunikasi Dakwah dan Komunitas Muslim}

Dari dua konsep di atas dapat dipahami bahwa komunikasi dakwah adalah komunikasi yang unsur-unsurnya disesuaikan visi dan misi dakwah. Menurut Toto Tasmara, bahwa komunikasi dakwah adalah suatu bentuk komunikasi yang khas dimana seseorang komunikator menyampaikan pesan-pesan yang bersumber atau sesuai dengan ajaran al Qur'an dan Sunnah, dengan tujuan agar orang lain dapat berbuat amal shaleh sesuai dengan pesan-pesan yang disampaikan. ${ }^{6}$

Jadi, dari segi proses komunikasi dakwah hampir sama dengan komunikasi pada umumnya, tetapi yang membedakan hanya pada cara dan tujuan yang akan dicapai. Adapun tujuan komunikasi pada umumnya yaitu mengharapkan partisipasi dari komunikan atas ide-ide atau pesan-pesan yang disampikan oleh pihak komunikator sehingga pesan-pesan yang disampaikan tersebut memberikan efek perubahan sikap dan tingkah laku yang diharapkan, sedangkan tujuan komunikasi dakwah yaitu mengharapkan terjadinya perubahan atau pembentukan sikap dan tingkah laku seseorang (komunikan) yang dalah bahasa dakwahnya adalah mad'u sesuai dengan tuntunan ajaran agama Islam yakni didasarkan pada nas-nask $\mathrm{Al}$-quan dan $\mathrm{Al}$-Hadits

Ditinjau dari sega bahasa (etimologi), dakwah berarti pangggilan, seruan, atau ajakan. Bentuk perkataan tersebut dalam bahasa arab disebut masdar, sedang bentuk kata kerja atau fi'ilnya adalah : Da'a (دعا) Yad'u ( دععو) yang mempunyai arti menyeru dan mengajak. ${ }^{7}$

Syeikh Ali Mahfud dalam kitabnya Hidayatul Mursyidin mengatakan bahwa Dakwah adalah Mendorong manusia untuk berbuat kebajikan dan mengikuti petunjuk agama dan menyeru kepada yang ma'ruf dan mencegah dari perbuatan mungkar agar mereka bahagia dunia dan akhirat. ${ }^{8}$

Dari berbagai definisi tersebut di atas, penulis dapat menyimpulkan bahwa dakwah adalah proses penyampaian pesan dan segala bentuk aktifitas yang diselenggarakan secara terencana di dalam menyampaikan ajaran-ajaran Allah kepada

\footnotetext{
6 Wahyu Ilahi, Komunikasi Dakwah, 24.

${ }^{7}$ H. Moh Ali Aziz, M. Ag., Ilmu Dakwah (Jakarta, Prenada Media, 2004),2.

8 Syeikh Ali Mahfudz Hidayah Mursyidin, Alih Bahasa Katijah Nasution, (Jakarta, Usaha Penerbitan 3 a, 1970), 4.
} 
individu ataupun masyarakat agar supaya tercipta suatu kehidupan yang dinamis dan islami dengan dilandasi oleh rasa cinta dan kasih sayang.

Penggunaan kata "komunitas" adalah sebuah pilihan yang lebi tepat, mengingat istilah masyarakat dalam pengertian yang lebih umum adalah orang-orang dalam jumlah relatif besar saling berinteraksi, baik antara individu dengan kelompok maupun kelompok antar kelompok, sehingga menjadi satu kesatuan sosial budaya tanpa mempertimbangkan perbedaan suku dan agama.

Sementara komunitas yang berasal dari bahasa Latin communitas yang berarti "kesamaan", kemudian communitas dapat diturunkan dari communis yang berarti "sama. Dalam komunitas manusia atau individu-individu di dalamnya dapat memiliki maksud, kepercayaan, sumber daya, preferensi, kebutuhan, risiko, kegemaran dan sejumlah kondisi lain yang serupa.

Jadi Komunitas adalah orang yang saling peduli satu sama lain dari yang seharusnya terjadi, dimana dalam sebuah komunitas terjadi relasi pribadi yang erat antar para anggota komunitas tersebut karena adanya kesamaan interest atau values. Komunitas juga dapat dikatakan sebagai sebuah identifikasi dan interaksi sosial yang dibangun dengan berbagai dimensi kebutuhan fungsional

Setidaknya definisi komunitas dapat didekati melalui beberapa hal; pertama, terbentuk dari sekelompok orang; kedua, saling berinteraksi secara sosial di antara anggota kelompok itu; ketiga, berdasarkan adanya kesamaan kebutuhan atau tujuan dalam diri mereka atau di antara anggota kelompok yang lain; keempat, adanya wilayahwilayah individu yang terbuka untuk anggota kelompok yang lain.

Jadi, komunitas muslim adalah kumpulan sekelompok orang yang saling berinteraksi dan mempunyai kesamaan dan kebutuhan tentang ke Islaman yang bertujuan untuk mengembangkan islam itu sendiri.

Terbentuknya komunitas Muslim di Desa Loloan Barat tidak lepas dari sejarah masukkan Ummat Islam ke Desa Loloan Barat sebagaimana yang telah dipaparkan secara singkat pada pendahuluan di atas. 


\section{Proses dan Pola Komunikasi}

\section{a. Proses Komunikasi}

Proses komunikasi yang bisa disampaikan dalam artikel ini terbagi menjadi dua tahap, yakni secara primer dan secara sekunder : ${ }^{9}$

1) Proses Komunikasi secara Primer

Proses komunikasi secara primer adalah proses penyampaian pikiran dan atau perasaan seseorang kepada orang lain dengan menggunakan lambang (symbol) sebagai media. Lambang sebagai media primer dalam proses komunikasi adalah pesan verbal (bahasa), dan pesan nonverbal (kial/gesture, isyarat, gambar, warna, dan lain sebagainya) yang secara langsung dapat/mampu menerjemahkan pikiran dan atau perasaan komunikator kepada komunikan.

Prosesnya sebagai berikut, pertama-tama komunikator menyandi (encode) pesan yang akan disampaikan disampaikan kepada komunikan. Ini berarti komunikator memformulasikan pikiran dan atau perasaannya ke dalam lambang (verbal/non verbal) yang diperkirakan akan dimengerti oleh komunikan. Kemudian giliran komunikan untuk menterjemahkan (decode) pesan dari komunikator. Ini berarti ia menafsirkan lambang yang mengandung pikiran dan atau perasaan komunikator tadi dalam konteks pengertian. Yang penting dalam proses penyandian (coding) adalah komunikator dapat menyandi dan komunikan dapat menerjemahkan sandi tersebut (terdapat kesamaan makna).

Hal itu sejalan dengan apa yang dikatakan oleh Wilbur Schramm, seorang Ahli Komunikasi kenamaan, dalam karyanya, communication Research in the United State, menyatakan bahwa komunikasi akan berhasil apabila pesan yang disampaikan oleh komunikator cocok dengan kerangka acuan (frame of reference), yakni paduan pengalaman dan pengertian (collection of experiences and meanings) yang pernah diperoleh komunikan. ${ }^{10}$

2) Proses Komunikasi secara Sekunder

${ }^{9}$ Onong Uchjana Effendy, Ilmu Komunikasi; Teori dan Praktek, 11.

${ }^{10}$ Onong Uchjana Effendy, Ilmu Komunikasi; Teori dan Praktek, 13. 
Proses komunikasi secara sekunder adalah proses penyampaian pesan oleh komunikator kepada komunikan dengan menggunakan alat atau sarana sebagai media kedua setelah memakai lambang sebagai media pertama. ${ }^{11}$

Seorang komunikator menggunakan media kedua dalam menyampaikan komunikasinya karena komunikan sebagai sasarannya berada di tempat yang relatif jauh atau jumlahnya banyak. Surat, telepon, teleks, surat kabar, majalah, radio, televisi, film, dan banyak lagi adalah media kedua yang sering digunakan dalam komunikasi. Dengan demikian, proses komunikasi secara sekunder ini menggunakan media yang dapat diklasifikasikan sebagai media massa (massmedia) dan media nirmassa atau media nonmassa (non-mass media).

\section{b. Pola Komunikasi}

Dalam Kamus Besar Bahasa Indonesia, pola merupakan arti dari model. Sedangkan pola sendiri berarti sistem, cara kerja, bentuk (struktur) yang tetap. ${ }^{12}$ Dalam kamus Ilmiah popular kata "pola" diartikan model, contoh: pedoman (rancangan), dasar kerja. ${ }^{13}$ Jadi pola juga dapat dikatakan model, yaitu cara untuk menunjukkan sebuah objek yang mengandung kompleksitas proses didalamnya dan hubungan antara unsur-unsur pendukungnya. ${ }^{14}$

Dari penjelasan di atas dapat dimpulkan bahwa Pola komunikasi merupakan model atau bentuk dari proses komunikasi, sehingga dengan adanya berbagai macam model komunikasi dan bagian dari proses komunikasi akan dapat ditemukan pola yang cocok dan mudah digunakan dalam berkomunikasi. Pola komunikasi identik dengan proses komunikasi, karena pola komunikasi merupakan bagian dari proses komunikasi.

Adapun pola-pola komunikasi yang dimaksud adalah:

1) Komunikasi Antarpribadi (Interpersonal Communication)

Komunikasi antar pribadi pada dasarnya merupakan jalinan hubungan interaktif antara seseorang individu dan individu lain dimana

\footnotetext{
11Onong Uchjana Effendy, Ilmu Komunikasi; Teori dan Praktek, 16.

${ }^{12}$ Kamus Besar Bahasa Indinesia, Offline, Versi 1.3.

13Pius Partanto, M. Dahlan Barry, Kamus Ilmiah Populer (Yogyakarta: Arkola2001), 613.

14Wiryanto, Pengantar Ilmu Komunikasi (Jakarta: Gramedia, 2004), 9.
} 
lambang-lambang pesan secara efektif digunakan, terutama lambanglambang bahasa.

Komunikasi antarpribadi pada umumnya dipahami lebih bersifat pribadi (private) dan berlangsung secara tatap muka (face to face). Menurut Effendy, pada hakikatnya komunikasi antar pribadi adalah komunikasi antara seseorang komunikator dengan seorang komunikan. jenis komunikasi tersebut dianggap paling efektif untuk mengubah sikap, pendapat, atau perilaku manusia berhubung prosesnya yang dialogis. ${ }^{15}$

Konsep "jalinan hubungan” (relationship) sangat penting dalam kejadian komunikasi antarpribadi “jalinan hubungan” merupakan seperangkat harapan yang ada pada partisipan yang dengan itu mereka menunjukkan perilaku tertentu didalam berkomunikasi. "jalinan hubungan" antarindividu hampir senantiasa melatarbelakangi pola-pola interaksi diatara partisipan dalam komunikasi antarpribadi.

Seseorang yang baru saja saling berkenalan cenderung berhati-hati di dalam berkomunikasi. Hal ini tampak, misalnya, ketika dalam menggunakan kata - kata mereka lebih selektif. Akan tetapi, seseorang yang bertemu dengan teman akrab cenderung terbuka dan spontan.

Relationship dalam konteks komunikasi antarpribadi tidak selamanya bersifat simetris. Tidak jarang terdapat kecenderungan dominasi dalam jalinan hubungan antarpribadi, secara relatif, kendatipun negosiasi senantiasa lebih mudah diupayakan dalam komunikasi antarpribadi dibanding dengan komunikasi manapun. Dalam hubungan ini, tujuan personal (atau kemungkinan lain tujuan sosial) menjadi faktor penentu kesepakatan (kecenderungan konvergensi) diantara partisipan komunikasi.

Kiranya dihipotesakan bahwa semakin personal (bersifat pribadi) suatu orientasi tujuan komunikasi maka akan semakin sulit diperoleh konvergensi. Begitu juga sebaliknya semakin bersifat sosial ( lebih luas dan keluar dari domain pribadi) orientasi tujuan atau maksud komunikasi maka akan semakin mudah dicapai kesepakatan.

${ }^{15}$ Alo Liliweri, Komunikasi Antarpribadi (Bandung: PT. Citra Aditya Bakti, cet. ke II, 2017), 12. 
Persoalan penilaian hubungan (the evaluation of relationship) merupakan persoalan lain yang penting dalam komunikasi antarpribadi. Dalam hubungan ini, dicakup setidaknya enam tahap atau tingkatan hubungan, yaitu:

a. Initiation.

Pada tahap ini, masing-masing partisipan saling membuat kalkulasi atau menaksir naksir satu dengan lain, dan mencoba mengupayakan penyesuaian - penyesuaian. Wujud dari penyesuaian disini misalnya, tersenyum, menganggukkan kepala, saling memperkenalkan diri dan mangucapkan kata - kata yang bersifat sopan santun atau basa - basi. Hubungan akan dilanjutkan ataukah tidak akan tergantung pada situasi yang berkembang kemudian.

b. Ekplorasi.

Pada tahap ini, partisipan saling berusaha mengetahui karakter orang lain, misalnya minat, motif dan nilai - nilai yang dipegang. Wujud dari ekplorasi ini, misalnya paritisipan saling mengajukan pertanyaan tentang kebiasaan, pekerjaan atau munkin tempat tinggal.

c. Intensifikasi.

Pada tahap ini partisipan saling bertanya pada diri sendiri apakah jalinan komunikasi diteruskan apa tidak. Kendatipun intesifikasi ini pada umumnya sulit diamati, namun yang menentuka apakah jalinan komunikasi diteruskan apa tidak adalah keyakinan akan manfaat dari jalinan komunikasi yang terbentuk atau setidaknya aktivitas komunikasi yang berlangsung, semakin diyakini manfaat yang diperoleh makan akan semakin berlanjut jalinan hubungan atau komunikasi yang berlangsung.

d. Formalisasi.

Pada tahap ini partisipan saling sepakat mengenai hal - hal tertentu, yang kemudian terformalisasikan kedalam berbagai tingkah laku, misalnya berjanji untuk saling bertemu lagi, menadatangani kontrak bisnis atau saling bercumbu. Sampai sejauh ini jalinan hubungan berjalan lancar dan harmonis. 
e. Redefinisi.

Pada tahap ini jalinan hubungan dan komunikasi yang ada dihadapan pada persoalan- persoalan baru dan silih berganti seiring dengan perjalanan waktu. Kecenderungan kembali saling menaksirnaksir satu dengan lain, membuat kalkulasi-kalkulasi baru tentang hubungan yang telah berjalan menjadi dominan. Hasil dari kalkulasi ulang ini akan menentukan apakah hubungan yang harmonis selama ini akan tetap harmonis ataukah justru akan menghadapi persoalan yang semakin berat.

f. Hubungan

Yang memburuk (deterioration). Gejala semakin memburuknya hubungan kadangkala tidak disadari sepenuhnya oleh partisipan komunikasi. Penyesuaian - penyesuaian telah senantiasa dicoba untuk diupayakan namun, didalam kenyataan, tidak selalu berhasil. Hal demikian terutama dikarenakan adanya perubahan struktur - struktur kepentingan, power dan orientasi partisipan yang saling berinteraksi dengan situasi eksternal. 16

2) Komunikasi Kelompok (group communication)

Bidang kajian ini pada dasarnya mempelajari pola-pola interaksi antarindividu dalam kelompok sosial (biasanya kelompok kecil dan bukan kelompok massa), dengan titik berat tertentu, misalnya pengambilan keputusan. Kecenderungan seperti ini didasarkan pada keyakinan bahwa pengambilan keputusan pribadi, misalnya ketika seseorang harus menentukan pilihan diantara kemunkinan-kemunkinan yang ada, berbeda dengan pengambilan keputusan yang harus dibuat secara bersama - sama dalam suatu kelompok.

Kendatipun terdapat perbedaan, namun seperti yang dikatakan oleh Follet, proses pengambilan keputusan dalam kelompok (dapat berlaku juga dalam konteks organisasi dan komunitas) ditandai dengan tiga tahapan penting, yakni :

${ }^{16}$ Brent D. RaRuben, "Pragmatism", dalam Edward Craig (general editor) Routledge Encylopedia of Philosophy Volume 7 (London: Routledge, 1998), 321-325. 
a. Mengumpulkan keterangan dari orang-orang yang dianggap banyak mengetahui atau munkin ahli,

b. Menguji keterangan-keterangan yang diperoleh dengan pegalamanpengalaman yang ada dalam kehidupan sehari-hari dan;

c. Mengembangkan cara atau jalan keluar dari persoalan yang dihadapi secara lebih integeratif memenuhi tuntutan-tuntutan yang berbedabeda ${ }^{17}$.

Beberapa kenyataan membuktikan bahwa didalam komunikasi kelompok, apabila hambatan interaksi antarpribadi rendah (yang berarti jalinan kerjasama antarindividu dalam kelompok tinggi) maka kelompok dapat bekerja secara lebih kohesif, dan tujuan bersama dapat lebih mudah dicapai.

3) Komunikasi organisasi

Komunikasi organisasional atau institusional berkenaan dengan komunikasi yang berlangsung dalam jaringan kerjasama antarpribadi dan/atau antarkelompok dalam suatu organisasi atau institusi. Beberapa diantara persoalan penting yang menjadi minat dari bidang komunikasi organisasional adalah peran tanggungjawab organisasi, struktur dan fungsi organisasi, serta budaya dan iklim organisasi. ${ }^{18}$

Konsep budaya organisasi dapat didefinisikan sebagai the sum of its symbols, events, standardizert verbal and nonverbal behavior patterns, folk tales, rules and ritual that give the organization its character or personality (simbol-simbol organisasi, kejadian-kejadian atau peristiwa-peristiwa yang menyangkut, baik organisasi, pola-pola perilaku verbal maupun nonverbal yang terstandardisasikan, kisah-kisah, ketentuan atau peraturan-peraturan dan upacara-upacara atau aktivitas bersiat ritual yang kesemuanya membentuk karakter atau kepribadian dari suatu organisasi).19

Jaringan komunikasi dapat dimaknai sebagai struktur hubungan antarindividu, bagian - bagian (devision, units), kelompok (clique) dalam suatu organisasi yang menunjukkan struktur kekuasaan,kekuatan,

\footnotetext{
${ }^{17}$ Littlejohn, Theories of Human Communication, 253

${ }^{18}$ Brent D. RaRuben, "Pragmatism", 357-379

${ }^{19}$ Brent D. RaRuben, "Pragmatism", 369
} 
pengaruh, kewenangan dan otoritas dalam organisasi. Jaringan komunikasi, dalam perspektif komunikasi organisasi, memiliki beberapa fungsi penting yang meliputi :

a. Mengkoordinasikan aktivitas individu, kelompok atau unit - unit lain dalam organization.

b. Memberikan mekanisme pengarahan organisasi secara keseluruhan.

c. Menfasilitasi pertukaran informasi dalam organisasi.

d. Mejamin adanya arus timbal balik (two-way flow information) antara organisasi dan lingkungan luar organisasi. 20

Kemudian, kalau organisasi dipahami sebagai suatu sistem jaringan komunikasi maka beberapa tradisi dapat diambil dalam melakukan kajian terhadap organisasi dilihat dari perspektif komunikasi. Jaringan (network) dalam hubungan ini dimaknai sebagai suatu struktur sosial yang tercipta oleh adanya komunikais diantara individu atau kelompok.

4) Komunikasi Massa (Mass Communication)

Littlejohn menawarkan definisi yang barangkali lebih memadai mengenai komunikasi massa dengan menyatakan bahwa komunikasi massa merupakan ... the process whereby media organizations prodice and transmit messages to large publics and the processby which those messages are sought, used, understood and influenced by audiences (proses dimana organisasi - organisasi media memproduksi dan menyampaikan pesan pesan kepada khalayak luas dan proses dimana pesan - pesan dicari, digunakan, dipahami dan dipengaruhi oleh khalayak). ${ }^{21}$

Perlu dipahami bahwa organisasi media massa bekerja sebagai suatu lembaga masyarakat (social institution) yang hidup ditengah masyarakat (dengan segala nilai, norma dan dinamikanya) dan berinteraksi dengan intitusi - intitusi lain yang ada didalam masyarakat.

${ }^{20}$ Brent D. RaRuben, “Pragmatism”, 364

${ }^{21}$ Littlejohn, Theories of Human Communication, 303 
Pandangan mengenai bidang kajian komunikasi masa cenderung bervariasi. Misalnya :

a. Media (isi dan struktur)

b. Hubungan - hubungan institusional media dengan strutur - struktur kemasyarakatan dan kebudayaan

c. Hubungan - hubungan personal individu khalayak dengan media

d. Dampak (impact) media terhadap masyarakat (pengaruh media secara makro), dan

e. Pengaruh (effect) media terhadap individu - individu (pengaruh media secara mikro). ${ }^{22}$

5) Komunikasi Budaya (cultural communication)

Komunikasi kultural disini tidak lain adalah komunikasi dengan menggunakan simbol-simbol yang berakar pada sejarah dan budaya masyarakat yang pada umumnya berlangsung secara apresiatif dan kadangkala juga bersifat lintas generasi. Artinya, generasi sekarang (abad ke-21) dapat mengapresiasi, misalnya candi borubudur yang dibangun pada abad ke- 8 atau musik jensi campur sari yang berkembang di indonesia di abad ke-20 ada kemunkinan dapat diapresiasi oleh generasi abad mendatang di Afrika Selatan atau Suriname.

Sampai tingkat tertentu, tampak ada semacam penggabungan anatara bentuk-bentuk komunikasi kultural tertentu dengan komunikasi massa, misalnya televisin (atau radio) menyiarkan wayang kulit, wayang orang, ludruk dan ketoprak. Akan tetapi, dari pengamatan menunjukan bahkan penyesuaian - penyesuaian terjadi mengingat media massa memiliki keterbatasan, terutama waktu (yang berimplikasi pada pembiayaan). Penyesuaian demikian, khususnya pada pertunjukan wayang kulit yang disiarkan melalui telivisi berarti bahwa pertunjukan dipersingkat dari lazimnya sekitar tujuh jam (pentas wayang kulit semalam suntuk) menjadi hanya dua jam pertunjukan di televisi. Hal demikian berarti pengurangan adegan, penghilangan tokoh yang dinilai sebagai pinggiran, pengurangan/penghilangan dialog serta gending

${ }^{22}$ Littlejohn, Theories of Human Communication, 303-330 
(iringan musik gamelan) dan penajaman fokus atau frame dari episode wayang kulit yang ditayangkan.

\section{Harmoni Sosial}

Dalam Kamus Besar Bahasa Indonesia harmoni berarti selaras atau serasi, ${ }^{23}$ sedangkan sosial berarti berkenaan dengan masyarakat, mengenai masyarakat, atau suka memperhatikan kepentingan umum ${ }^{24}$. Sedangkan menurut Enda M.C social adalah cara tentang bagaimana individu saling berhubungan sosial secara baik dan saling menghargai satu sama lain ${ }^{25}$. Harmoni sosial adalah kondisi dimana individu hidup sejalan dan serasi dengan tujuan masyarakatnya. Harmoni sosial juga terjadi dalam masyarakat yang ditandai dengan solidaritas ${ }^{26}$. Harmoni Sosial suatu keadaan keseimbangan dalam sebuah kehidupan, dua kata yang saling berkesinambungan dan memiliki arti kata yang tidak dapat dipisahkan merupakan keadaan yang selalu didambakan oleh masyarakat dalam kehidupan mereka.

Keharmonisan akan terwujud jika didalamnya ada sikap saling menghargai dan menyayangi antar anggota keluarga atau masyarakat. Dari kedua gabungan kata tersebut dapatlah diperoleh kesimpulan yang menggambarkan cita-cita tinggi dari kehidupan bermasyarakat, harmoni sosial tidak akan pernah tercapai ketika tidak tercipta kehidupan yang damai serta saling menghargai dari setiap anggota masyarakat yang tinggal bersama dan memiliki perbedaan. Keberadaan manusia bersama dengan sesamanya merupakan kenyataan yang tidak dapat disangkal. Tidak mungkin hidup tanpa orang lain, suatu masyarakat akan berada dalam ketertiban, ketentraman, dan kenyamanan bila berhasil membagun harmoni sosial.

Banyak hal yang berkaitan dengan harmoni sosial, baik dari aspek ideologi, politik, ekonomi, budaya, pertahanan, dan keamanan. Harmoni kehidupan manusia dalam sistem negara bangsa bisa berkembang dengan baik

\footnotetext{
23 Meity Taqdir Qodratillah dkk., Kamus Besar Bahasa Indonesia (Jakarta: Badan Pengembangan dan Pembinaan Bahasa Kementerian Pendidikan dan Kebudayaan, 2011), 156.

24 Ibid., 506.

25 Amal Taufiq, "Adaptasi Budaya dan Harmoni Sosial: Proses Adaptasi Mahasiswa Malaysia di Surabaya" (Skripsi Tidak diterbitkan, Jurusan Sosiologi Fakultas Sosial Politik UIN Sunan Ampel, 2014), 27.

26 Wahyu Nur Mulya, "Perbedaan, Kesetaraan, dan Harmoni Sosial", blog.unnes.ac.id/warungilmu/2015/12/18/perbedan-kesetaraan-dan-harmoni-sosialsosiologi (Jumat, 7 April 2017, 08.30) digilib.uinsby.ac.id digilib.uinsby.ac.id digilib.uinsby.ac.id digilib.uinsby.ac.id digilib.uinsby.ac.id digilib.uinsby.ac.id digilib.uinsby.ac.id 24
} 
jika pemeluk beragam agama berhenti menjadikan Tuhan dan agama yang dipeluknya sebagai topeng kerakusan kekuasaan, dan kekayaan materiil. Kecenderungan demikian sering kali terjadi akibat kemanusiaan diletakkan sebagai negasi sempurna ketuhanan. The others atau keberlainan dalam pandangan multikulturalisme adalah unsur terpenting dari kehidupan sosial yang terbuka dan demokratis. The others adalah akar keberadaan setiap orang, etnis, bangsa, dan setiap agama atau paham keagamaan ${ }^{27}$.

Kehidupan masyarakat Indonesia yang berasal dari latar belakang yang beragam suku, budaya, agama, tradisi, pendidikan, ekonomi, dan sebagainya adalah sesuatu yang niscaya dan tidak dapat dielakkan oleh setiap individu. Namun di situlah keindahan sebuah komunitas sosial bila mampu merekat berbagai perbedaan itu dan menjadikannya sebagai sarana untuk saling memahami, tepo seliro dan toleransi, yang akhirnya akan melahirkan persatuan dan saling mencintai ${ }^{28}$. Pada kenyataannya ditengah masyarakat kita berbagai perbedaan itu kerap menjadi sumbu pemicu terjadinya konflik horizontal berkepanjangan. Tentu banyak variabel penyebab munculnya berbagai konflik.

Bahkan bisa jadi konflik membara dapat muncul dari sebuah komunitas yang berasal dari latar belakang budaya, ekonomi, suku, dan pendidikan yang sama. Konflik seperti ini kerap terjadi pada masyarakat Indonesia yang hidup di pedalaman dan tidak memiliki pendidikan memadai untuk mengomunikasikan maslah yang terjadi ditengah mereka. Sehingga bagi mereka bahasa otot jauh lebih efektif untuk menyelesaikan maslah tersebut ketimbang bahasa otak ${ }^{29}$. Konflik dapat terjadi dimana saja pada siapa saja dan komunitas manapun, tidak peduli apakah ia berasal dari kalagan terpelajar, suku atau agama yang sama.

Setiap orang dapat terlibat dalam arus konflik yang terjadi dihadapannya, atau bersentuhan langsung dengannya kecuali mereka yang memiliki pikiran yang jernih, hati yang lapang dan kendali nafsu yang kuat. Perbedaan budaya, kultur, dan tradisi suatu wilayah dengan wilayah yang lain juga akan menghasilkan karakter yang berbeda. Inilah salah satu kekayaan bangsa kita yang terdiri dari banyak suku tersebar di berbagai wilayah. Sebagaimana

\footnotetext{
${ }^{27}$ Abdul Munir Mulkhan, Satu Tuhan Seribu Tafsir (Jakarta: Kansius, 2007), 65.

${ }^{28}$ Benyamin F. Intan dkk., "Kearifan Lokal Masyarakat Nias", Societas Jurnal Agama dan Masyarakat DEI, Vol. 1, No 1, (Oktober, 2014), 247.

${ }^{29}$ Ibid.,248
} 
disebutkan di atas bahwa berbagai perbedaan tersebut dapat menjadi pemicu munculnya sebuah konflik bila tidak dikelolah dengan baik

Harmonitas sosial dicapai jika tidak terjadi konflik-konflik sosial. Bukan berarti dengan adanya keberagaman dan perbedaan di masyarakat itu lalu disebut sebagai konflik. Karena adanya perbedaan dan keberagamanlah merupakan bagian dari syarat terwujudnya keharmonisan sosial. Jadi harmoni di sini sebenarnya merujuk pada keselarasan lahir batin yang ada pada diri individu dan sosial. 30

\section{Upaya Menjaga Harmoni Sosial di Loloan Jembrana Bali}

Masyarakat Loloan dalam menjalani aktifitas sehari-hari mereka tetap mempertahankan nilai lokal yang telah ada dan tumbuh serta menjadi suatu kebudayaan yang merupakan ciri khas masyarakat Loloan. Seperti masalah bahasa, pakaian, makanan, dan tradisi masyarakat yang lainnya. Dalam masalah bahasa, masyarakat Loloan menggunakan bahasa Melayu asli dan Bahasa Bali. Bagi orang-orang Muslim, mereka tetap menggunakan bahasa Melayu asli pada saat mereka menjalin komunikasi dengan antar sesama umat Muslim atau Hindu. Karena sudah menjadi tradisi bahasa yang digunakan.

Berikut tradisi masyarakat Desa Loloan yang menggambarkan sebuah jalinan yang memiliki nilai toleransi agama yang sangat tinggi diantaranya:

\section{a. Ngejot}

Istilah ngejot itu merupakan sebuah sebutan bagi masyarakat Loloan yang memiliki makna berbagi. Khususya di Desa Loloan baik orang-orang Muslim maupun Hindu, ketika mereka memiliki acara selametan atau upacaraupacara keagamaan, seperti, pada saat hari Raya Idul Fitri maupun Idul Adha, Maulid Nabi, Pengajian Umum, Ngeruah, ${ }^{31}$ nelai, 32 walimah dan lainnya, disitulah orang-orang Muslim memiliki kesempatan berbagi makanan kepada orang Hindu.

\footnotetext{
${ }^{30}$ Moh. Roqib, Harmoni dan Budaya Jawa (Purwokerto: STAIN Purwokerto Press, 2007), 2.

${ }^{31}$ Ngeruah merupakan sebutan bagi Masyarakat Loloan Barat khususnya yang Bergama Muslim yang merupakan sebutan untuk sebuah selametan dalam rangka memperingati kematian keluarga atau kerabat yang telah meninggal. Dengan kata lain istilah ngeruah sama halnya dengan haul.

32 Nelai merupakan sebuah istilah bagi orang-orang Muslim Desa Loloan Barat. Kata Nelai sama halnya dengan acara potong rambut bagi bayi yang baru lahir. Biasanya Nelai tersebut dilaksanakan pada bayi yang berusia tujuh hari atau sudah putus tali pusarnya.
} 
Sedangkan orang Hindu juga demikian, mereka saling berbagi makanan antara yang satu dengan yang lainnya pada saat mereka mengadakan upacara keagamaan, seperti ngaben, potong gigi, pernikahan, dan sebagainya. Dalam hal berbagi makanan, mereka mengerti terhadap makanan yang akan mereka berikan kepada yang bersangkutan. Karena kita tahu, bahwa Masyarakat Loloan merupakan masyarakat yang heterogen. Sehingga dalam tradisi seperti ini mereka lebih mengutamakan kebersamaan dan kekeluargaan sebagai masyarakat desa.

\section{b. Nyepi}

Nyepi merupakan sebuah acara keagamaan umat Hindu yang diadakan setiap satu tahun satu kali. Biasanya pada saat acara berlangsung umat Hindu tidak keluar rumah dalam waktu 24 jam. Begitu juga dengan umat Muslim, karena ketika datang Hari Raya Nyepi, mereka juga ikut menghormati umat Hindu dengan cara tidak keluar rumah serta ikut menjaga lingkungan setempat, agar prosesi Nyepi pada saat itu berjalan lancar tanpa adanya gangguan-gangguan.

Saat menjalani Nyepi, lanjut dia, umat Hindu memiliki empat pantangan yang tidak boleh dilanggar. Biasa disebut dengan Catur (Brata) Penyepian.

1. Tidak boleh menyalakan api (amati Geni)

Api adalah simbol hawa nafsu. Pada hari Nyepi, umat Hindu berkontemplasi tanpa menyalakan api atau adanya cahaya untuk mengendalikan hawa nafsu yang disimbolkan dengan api.

2. Tidak bekerja (amati Karya)

Umat Hindu kembali melakukan evaluasi dalam suasana hening tentang apa yang sudah dikerjakan, apakah sudah sesuai dengan kemampuan dan perhitungan yang matang. Manusia pada dasarnya perlu istirahat dan tidak bekerja secara berlebihan. Melalui amati Karya ini, manusia dapat melihat ke dalam untuk memutuskan apa yang harus dikerjakan di masa yang akan datang sesuai kemampuan dan perhitungan yang tepat.

3. Tidak bersenang-senang (amati Lelanguan)

Pada hari Nyepi, manusia tidak mencari kesenangan atau hiburan yang bersifat duniawi. Manusia mengendalikan diri dengan memberikan 
hiburan batin. Nafsu untuk berfoya-foya atau dikendalikan kesenangan duniawi.

4. Tidak berpergian (amati Lelungan)

Tubuh perlu diistirahatkan. Sambil melihat selama tahun yang lewat sudah sukses atau tidak. Apakah sesuai harapan atau tidak sehingga bisa memperbaiki diri di tahun yang baru.

"Empat hal itu intinya melihat ke dalam menggunakan mata batin apa yang telah terjadi. Bagaimana relasi kita selama ini dengan sesama, Tuhan dan alam semesta," kata ketua PHDI Bali I Gusti Ngurah Sudiana33.

\section{c. Galungan Kuningan}

Galungan Kuningan juga termasuk acara keagaamaan umat Hindu yang ada di Loloan. Tidak hanya di Loloan, seluruh umat Hindu yang ada di Bali, juga ikut merayakannya. Biasanya menjelang Hari Raya Galungan Kuningan sampai acara berlangsung pedagang-pedagang di pasar, sekolah, sampai instansi-instansi perkantoran juga ikut meliburkan diri pada saat itu. di sini, umat Muslim juga ikut meliburkan diri dari berbagai aktifitas, terutama aktifitas bekerja. Mereka menunggu sampai prosesi acara Galungan Kuningan selesai, barulah mereka mulai menjalankan aktifitas pekerjaannya sebagaimana biasa.

Setiap menjelang hari Raya Galungan, pastilah orang Hindu menerima dan mengirim-membuat ucapan selamat baik secara langsung maupun melalui media, seperti surat kabar, majalah, TV, SMS, dsb. Jika dibaca dan dihayati ucapan itu begitu Indah dan melankolis. Tapi yang ada sesungguhnya kita lebih banyak membohongi diri sendiri, karena apa yang kita ucapkan dan kita buat kita belum bisa melakukannya atau belum dapat meraihnya, yaitu jadi Pemenang atas Dharma Jati Diri melawan Adharma yang ada dalam diri ini juga.

Kata Galungan berasal dari bahasa Jawa Kuno yang berarti; menang atau bertarung. Galungan juga sama artinya dengan Dungulan dalam Bahasa Bali Kuno. Hari Raya Galungan sudah dirayakan terlebih dahulu di tanah Jawa, ini sesuai dengan lontar berbahasa Jawa Kuno yaitu : Kidung Panji Amalat Rasmi.

\footnotetext{
33 http://travel.tribunnews.com/2017/03/24/menelisik-4-filosofi-di-balik-kesunyian-hari-raya-nyepiumat-hindu
} 
Di Bali Hari Raya Galungan untuk pertama kali dilaksanakan pada Hari Purnama Kapat, Budha Kliwon Dungulan tahun Saka 804 atau tahun 882 Masehi ini sesuai dengan lontar "Purana Bali Dwipa”

\section{d. Kotekan}

Istilah kotekan sama halnya dengan jenis musik tradisional yang sebagian alatnya-alatnya terbuat dari bambu. Biasanya masyarakat Loloan ketika menjelang Hari Raya Idul Fitri, mereka mengadakan kegiatan Lomba Kotekan, yang pesertanya terdiri dari seluruh anak-anak muda yang ada di Harmoni sosial. Biasanya juga acara tesebut berlangsung malam hari, dengan cara memainkan musik kotekan tersebut sambil berjalan mengelilingi Desa Loloan Barat, baik itu dari Loloan, Timur sampai Tengah. Umat Hindu pada saat acara berlangsung, mereka tidak merasa terganggu, bahkan mereka juga ikut meramaikan serta ikut mengamankan jalannnya kegiatan pada saat itu.

\section{Komunikasi Dakwah di Loloan Jembrana Bali}

Sebagai muslim mayoritas tentu mereka menginginkan pesan-pesan agama Islam bisa tersampaikan dengan baik diseluruh daerah Loloan. Bisa sebagai spirit dan juga atas kewajiban karena mereka paham bahwa menyampaikan dakwah merupakan kewajiban bagi setiap ummat islam.

Akan tetapi merekapun sadar bahwa disekitar mereka ada komunitas lain yang berbeda dengan mereka yang harus mereka hargai dan jaga perasaanya, sehingga menyampaikan dakwah harus dengan menggunakan strategi yang tepat yang bisa mencapai kedua-duanya yaitu dakwah bisa disampaikan dan tetap terjalin hubungan yang baik dengan komunitas lain khususnya komunitas Hindu.

Salah seorang tokoh Islam yang juga berprofesi sebagai guru yang bernama Pak Muhlisin menuturkan;

"walaupun disini mayoritas Islam, kita tidak melakukan dakwah kerumahrumah orang hindu, karena itu akan membuat mereka tersinggung dan terganggu dan bisa membuat hubungan kami disini menjadi tidak baik. Akan tetapi dakwah dilakukan dengan proses yang mengalir begitu saja, misalnya dengan mendirikan pendidikan agama seperti TPQ, Madrasah dan majlis-majlis ta'lim" 34

Bagi penulis, ini cukup masuk akal, mengingat komunitas muslim Loloan adalah muslim mayoritas di dalam agama Hindu yang mayoritas. Hal ini wajar

34 Wawancara dengan pak Mukhlisin Mei 2017 
karena Loloan adalah salah satu desa yang berada di Provinsi Bali yang menjadi provinsi dengan jumlah penduduk beragama Hindu paling banyak.

Oleh karena itu, beberapa hal yang menjadi prioritas komunitas muslim dalam melakukan dakwah adalah:

1. Menjaga simbol-simbol sejarah Islam Loloan

Di desa loloan terdapat beberapa peninggalan sejarah yang menjadi bagian penting bagi ummat islam Loloan, diantaranya adalah

a. Makam Keramat Buyut Lebay yang terletak di Loloan Timur.

Salah satu upaya menjaga peninggalan Islam di tanah Loloan maka masyarakat muslim Loloan menjadikan Makam Buyut Lebay menjadi salah satu objek wisata religi yang cukup menarik banyak wisatawan baik dari dalam maupun dari luar negeri. Mbah Buyut Lebay sendiri dikenal sebagai salah satu penyebar Islam di tanah Loloan sejak 1765, beliaulah yang mengenalkan agama dan bahasa Melayu kepada penduduk Bugis yang sudah lebih awal mendiami Desa Loloan Barat.

b. Masjid Jamik al-Mujahidin yang konon sudah berdiri lebih dari 200 tahun.

c. Masjid Agung Baitul Qodim di Loloan Timur yang konon sudah berusia 4 abad.

Masjid ini dibangun sebagai salah satu lambang kedatangan Islam di tanah Loloan dan juga bersatunya Melayu dan Bangsa Bugis.

d. Pondok Pesantren yang sampai saat ini masih aktif "PP. Mambaul Ulum" yang berdiri 1935.

Menjaga warisan sejarah Islam menjadi bagian yang tak terpisahkan dari upaya untuk terus melakukan syi'ar Islam, terutama kepada generasigenerasi muda Islam, mereka harus tahu bahwa pendahulu-pendahulu mereka secara konsisten dan istiqomah mengajarkan serta menyebarkan Islam di Desa Loloan Barat dengan sangat damai tanpa ada penolakan dari perintah ataupun penguasa Jembrana pada saat itu.

Hasilnya kemudian bisa dinikmati saat ini, Desa Loloan Barat menjadi salah satu kampung paling damai di Provinsi Bali menjadi komunitas muslim mayoritas dengan tetap tunduk dan patuh kepada ketentuan-ketuan yang berlaku baik di Bali ataupun perintah Negera Kesatuan Republik Indonesia. 
2. Mendirikan lembaga pendidikan Islam

Lembaga pendidikan yang ada di Desa Loloan Barat cukup beragam karena melihat situasi dan kondisi masyarakat. Lembaga formal yang tedapat di Loloan antara lain yakni: Paud dan TK, SDN 1 Loloan Timur dan SDN 1 Loloan Barat. Selain SD, di Loloan juga terdapat dua MI; (1) MIN Loloan Timur dan (2) MI Mujahidin Loloan Barat.

3. Mendirikan Majlis Ta'lim

Majlis ta'lim yang ada di Desa Loloan merupakan upaya untuk memberikan pendidikan agama secara umum kepada umat Islam dalam rangka menjaga akidah dan pemahaman mereka di dalam melaksanakan ajaran Islam yang benar sesuai dengan tuntunannya.

Majlis ta'lim yang ada di Loloan ada yang berupa pengajian rutin malam Selasa dan ba'da subuh pada hari Ahad dengan mendatangkan beberapa kiai, habaib dan ustadz secara bergiliran yang langsung dikoodrinir oleh pengurus takmir masjid Jami’ Nurul Huda Loloan Timur.

\section{KESIMPULAN}

Demikian kajian hasil penelitian tentang Pola Komunikasi Dakwah dalam menjaga Harmoni Sosial di Desa Loloan Barat Jemberana Bali. Dari penjelasan di atas dapat disimpulkan bahwa: pertama, Memahami konsep kehidupan berbangsa dan bernegara haruslah tepat dan benar, menerima perbedaan yang terjadi ditengah-tengah masyarakat yang plural haruslah diangap sebagai sebuah kekayaan dan kesempatan untuk bisa saling menghargai dan bersatu untuk kepentingan bangsa dan negara. Penerimaan atas perbedaan suku, ras, agama dan status sosial adalah sebua keniscayaan untuk keberlangsungan kehidupan berbangsa dan bernegara.

Kemudian yang kedua, di dalam upaya mendakwahkan Islam ditengahtengah komunitas non Muslim dalam hal ini adalah Hindu, maka perlu dilakukan dengan memperhatikan aspek-aspek yang tidak akan mencederai keharmonisan yang selama ini terjalin dengan sangat baik. Diperlukan kecerdikan dan strattegi yang tepat sehingga dakwah yang dilakukan bisa berjalan dengan baik dan tidak mengganggu harmoni sosial di masyarakat. Ketiga, diperlukan upaya yang dilakukan secara bersama-sama dengan prinsip saling menghormati dan 
menghargai kegiatan ibadah masing-masing pemeluk agama. Bahkan beberapa kegiatan ibadah bisa dilakukan secara bersama-sama, misalnya saling bersilaturrahim pada saat hari raya, saling membantu saat ada acara perkawinan dan semacamnya.

Semoga kajian ini bisa bermanfaat bagi penulis dan bagi siapapun yang membaca tulisan ini.

\section{DAFTAR PUSTAKA}

Ahmady, Noor. 2013. "Pesantren dan Kewirausahaan. (Peran Pesantren Sidogiri Pasuruan dalam Mencetak Wirausaha Muda Mandiri”. Laporan Penelitian: IAIN Sunan Ampel, Surabaya.

Al-Bayanuny, Muhammad Abd. al-Fath,2011. Al-Madkhal Ila 'Ilmi Al-Da'wah, Beirut :

Reshalah Publisher.

Amin, Syamsul Munir. 2009. Ilmu Dakwah. Jakarta: Amzah.

Amrullah, Zen. 2012.“Reproduksi Ulama di Pesantren Sidogiri Pasuruan”. Tesis--IAIN Sunan Ampel, Surabaya.

Arifin, H. 1977. Psikologi Dakwah. Jakarta: Bulan Bintang.

Aziz, Moh. Ali. 2014. Ilmu Dakwah. Jakarta: Kencana.

Chotimah, Chusnul. 2012."Strategi Public Relation Pesantren Sidogiri Dalam Membangun Citra Lembaga Pendidikan Islam". Islamica, Vol. 7, No. 1. September.

Creswell, John W. 3013. Reseach Design: Pendekatan Kualitatif, Kuantitatif, dan Mixed Edisi Ketiga. Yogyakarta: Pustaka Pelajar.

Fatoni, Muhammad Sulton. "Strategi Organisasi Pondok Pesantren Sidogiri dalam Mewujudkan civil society: Analisa Kapital Sosial”. Tesis--UI, Jakarta, 2007.

Ghony, M. Djunaidi dan Fauzan Almanshur, Metodologi Penelitian Kualitatif, Jogyakarta, Arruz Media, 2010.

Hadi, Moh. Sofwan. 2009."Eksistensi Pondok Pesantren Tradisional Sidogiri Kraton Pasuruan Pada Era Modernisasi”. Skripsi--UIN Malik Maulana Ibrahim, Malang.

Ilahi, Wahyu.2013. Komunikasi Dakwah, (Bandung: PT Remaja Rosdakarya)

Ismail, Faisal. 2014. Dinamika Kerukunan Antarummat Beragama, (Bandung:PT. Remaja Rosda Karya) 
Moleong, Lexy J. 2007. Metodologi Penelitian Kualitatif. Rosda Karya.

Mulkhan, Abdul Munir. 1993. Paradigma Intelektual Muslim. Yogyakarta: Sipress.

Munawir, Ahmad Warson. 1984. Kamus Arab Indonesia. Yogyakarta: al-Munawwir.

Saefulloh, Aris. “Cyberdakwah Sebagai Media Alternatif Dakwah”, Islamica, Vol. 7, No. 1. September, 2012.

Shihab, M. Quraish, 1994. Membumikan Al-Qur'an: Fungsi dan Peran Wahyu Dalam Kehidupan Masyaraka. Bandung: Mizan.

Sugiono. 2009.Metode Penelitian Pendidikan: Pendekatan Kualitatif, Kuantitatif, dan R \& D. Bandung: Alfabeta.

Suryana. 2010. Metodologi Penelitian: Model Praktis Penelitian Kuantitatif dan Kualitatif. Jakarta: Universitas Pendidikan Indonesia.

Tim Penyusun Kamus Pusat Bahasa. 2002. Kamus Besar Bahasa Indonesia. Jakarta: Balai Pustaka.

Tim Redaksi. Tamassya: Laporan Tahunan Pengurus Pondok Pesantren Sidogiri 14331434 H, edisi 11,Pasuruan: Sekretariat PPS, 1434 ) 